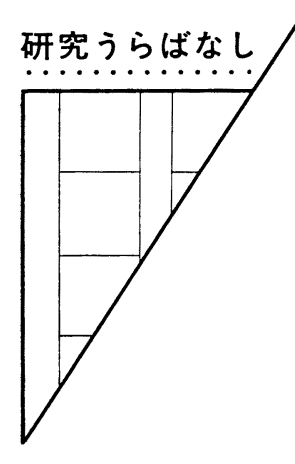

\title{
フラビン・金属酵素
}

\section{伊賀上郁夫 新潟大学農学部}

今から 20 年ほど前, 私はハワイ 大学太平洋医学研究所のヤスノブ教 授の研究室に留学中で, モノアミン 酸化酵素 (MAO) の研究をしてい た。それよりさき, 現京大農学部山 田秀明博士が同じ研究室におられ， 牛血漿 MAO を精製, 結晶化された。 分子量 $260 \mathrm{KD}$ 当たり銅 4 グラム原 子とピリドキサールリン酸 2 モルを 含むピンク色の興味ある酵素で当時 大変話題になったものである。

イプロニアチドは強力な $\mathrm{MAO} の$ 阻害剂で，これを動物に投与した場 合, とくに脳内の芳香族アミンの分 解が阻害され, 七ロトニン, カテュ ールアミン，ドーパミンなど神経系 の機能と密接な関係がある物質の含 量が増加することから, 生理, 薬理, 生化学的に MAO の阻害といら方向 で広く研究が行われ, 抑らつ病, 八 一キンソン病, 狭心症などに有効と された。米国ではこれら疾患が多く, $\mathrm{NIH}$ やNASA などから豊富な研 究費が投入されていた。

一方, MAO にはミトコンドリア (Mit) 膜表面に強く結合して存在す る酵素があり, 多くのレビューがこ の酵素の可溶化, 分離の困難性を指 摘していた。ヤスノブ研でも上記血 漿 MAO につついてのチ+レンジ ングワークとしてカが入れられてい た。その時期, 現長崎大薬学部鶴大 典博士の御推薦で, この仕事が如何 に大変であるかは夢にも思わずのこ
のこ出かけた次第であった。

すでにヤスノブ研では牛肝 Mit から部分精製された MAO がフラ ビンを含み, かつ活性度と銅含量が 平行的に増加することから，血漿の 場合と同じく銅の存在を示してい た。しかしこれより古く, 緑色をし たブチリル〜 CoA 脱水素酵素が 牛肝から抽出, 精製され, 分子量 $(120 \sim 220 \mathrm{KD})$ 当たり $5 \sim 6$ モル のFAD と $10 \sim 12$ グラム原子の銅 を含み，銅の機能についても基質か らフラビン, 銅を介しての電子の流 れについての見事な実験的見解が H. R. マーラー, D. E. グリーンらの 大御所によって発表されており, 実 験化学講座 24 巻 (丸善) にも引用 されている。

ところが私がハワイ大に行った 1965 年にはこの酵素の銅の存在は 否定されていたのである。以後私は この酵素の構造と機能の解明にとつ 組むことになる。

ハワイは常夏の国, 室内は毎日 $30^{\circ} \mathrm{C}$ の快適な気候であるのにその $2 / 3$ を $4^{\circ} \mathrm{C}$ の低温室で過すようにな ろらとは皮肉なものであった。1年 余り, 酵素の精製が進み, 当時の世 界のレベルからみても最高の比活性 をもつ輝黄色の安定な標品を得た。 そのフラボペプチドの分析から FAD は共有結合で配位しているこ と, 銅の存在については慎重な立会 い実験も行ったが，用いたどの方法
でも有意の量は認められないことな どが明らかになった。

その後本酵素は分子量 $405 \mathrm{KD}$ と 1, $280 \mathrm{KD}$ の大きな 2 成分からなり， 前者は分子当たり 4 モル FAD, 24 モルホスフォリピッドの構成で, 後 者は前者の 3 量体と考えられた。

その後動物の Mit 酵素は FAD, 微生物では銅のみの存在が示され た。すなわちモノアミン: $\mathrm{O}_{2}$ 酸化 還元酵素（脱アミノ）はフラビンを 含む酵素 (EC 1，4，3，4）と銅を含 む酵素 (EC 1，4，3，6) が存在する が, フラビンと銅を併せもつ MAO は存在せず, 過去いくらかの研究者 が過ちを扮か寸結果となった。この 点対照的なのはフラビンと非へム鉄 を併せもつコハク酸一, アルデヒ ドー，脱水素酵素などで，これらは いずれも不安定型硫黄をもつ特長が ある。

㷌国後, イネ細胞の酸性ホスファ ターゼの仕事を始め, 紫色の酵素を 単離した。同じ頃京大薬学部上原教 授らもサッマイモから同様な紫色酵 素を見出していた。いずれもマンガ ンを含むめずらしい酵素であること が判明した。

金属酵素とはなかなか縁が切れな いようである。 